\title{
Reproductive life history of Heterandria bimaculata (Heckel, 1848) (Poeciliinae: Poeciliidae) in the Honduran interior highlands: trait variation along an elevational gradient
}

\author{
Charles T. Olinger ${ }^{1}$, Brandon K. Peoples ${ }^{1,2}$ and Emmanuel A. Frimpong ${ }^{1}$
}

This study examined reproductive traits and growth rates of Heterandria bimaculata (Poeciliidae) in Cusuco National Park (CNP), a cloud forest reserve in northern Honduras, Central America. In CNP, H. bimaculata occurs in the absence of other fish species and major invertebrate predators along an approximately $1000 \mathrm{~m}$ elevation gradient. This allowed for the examination of trait variation along the gradient without the confounding effects of interspecific interactions or habitat patchiness. Heterandria bimaculata exhibited traits characteristic of a low-predation environment: balanced sex ratio, slow growth, late maturity and large female size. Females produced more, smaller eggs from upstream to downstream, but overall reproductive allocation remained constant along the gradient. Maximum male length and annual growth rates increased from upstream to downstream, but female growth showed no trend. The patterns of growth and reproductive allocation tradeoff are consistent with predicted response to a longitudinally-increasing productivity gradient in which food resources become more abundant downstream. Macrobrachium and Bellastoma could have caused some predation, but were sparse and patchily distributed. Fish density remained fairly constant among elevations; if food resources were limiting in upstream habitats, per-capita resource availability would be lower and density-dependent competition would drive selection for larger but fewer, more competitive offspring. Future work should quantify longitudinal changes in productivity and conduct experiments to decouple the effects of stream order and fish density dependence.

Este estudo analisou características reprodutivas e taxas de crescimento de Heterandria bimaculata (Poeciliidae) no Parque Nacional de Cusuco (CNP), uma reserva florestal nubosa no norte de Honduras, América Central. No CNP, $H$. bimaculata ocorre na ausência de outras espécies de peixes e grandes predadores invertebrados, ao longo de um gradiente de aproximadamente $1.000 \mathrm{~m}$ de altitude. Isto permitiu a análise de variação das características ao longo do gradiente sem a interferência dos efeitos de interações interespecíficas ou desconexão de hábitat. Heterandria bimaculata exibiu traços característicos de um ambiente de baixa predação: proporção sexual equilibrada, de crescimento lento, maturidade tardia e fêmeas de grande porte. As fêmeas produzem mais ovos menores de montante para jusante, mas a alocação reprodutiva global manteve-se constante ao longo do gradiente. O comprimento máximo dos machos e as taxas de crescimento anual aumentaram da montante para jusante, mas o crescimento as fêmeas não mostrou nenhuma tendência. Os padrões de crescimento e alteração de alocação reprodutiva são consistentes com a resposta prevista para um gradiente de produtividade que aumenta longitudinalmente, no qual os recursos alimentares se tornam mais abundantes a jusante. Macrobrachium e Bellastoma poderiam ter causado alguma predação, mas foram escassos e pouco distribuídos. A densidade de peixes manteve-se relativamente constante entre as elevações; se os recursos alimentares fossem limitantes em hábitats a montante, a disponibilidade de recursos per capita seria menor e a competição dependente da densidade iria conduzir a seleção para uma prole mais competitiva, maior mas menos numerosa. Trabalhos futuros deverão quantificar as mudanças longitudinais na produtividade e conduzir experimentos para dissociar os efeitos da ordem do riacho e dependência da densidade de peixes.

Keywords: Central America, Fecundity, Growth rate, Livebearer, Offspring size.

\section{Introduction}

Relative to North and South America, the freshwater fishes of Central America are poorly studied. Despite recent gains toward understanding the biogeography of
Central American freshwater fishes (Matamoros et al., 2012, 2015), very little is known about the distribution and basic ecology of fishes in the small upland streams of the interior highlands (Miller, 1966, Lyons, 2005, Esselman et al., 2006). Livebearers (Poeciliidae) comprise

\footnotetext{
${ }^{1}$ Department of Fish and Wildlife Conservation, Virginia Polytechnic Institute and State University. 100 Cheatham Hall, Blacksburg, VA, USA 24061. (CTO) colinger@vt.edu, (BKP) bpeoples@vt.edu, (EAF) frimp@vt.edu (corresponding author)

${ }^{2}$ Operation Wallacea. Wallace House, Old Bolingbroke, Spilsby, Lincolnshire, PE23 4EX, UK
} 
a substantial portion of the Central American freshwater fish diversity, and are common in most aquatic habitats throughout the region (for example, Matamoros et al., 2009, 2012, 2015; McMahan et al., 2013; Angulo et al., 2013). In fact, poeciliids often are the only taxon of fishes occurring in high-elevation Central American streams. Much research attention has been devoted to life histories of poeciliid species inhabiting North America and the Caribbean islands (e.g. Magurran, 2005), but far less is known about poeciliids inhabiting mainland Central America. The freshwater habitats of mainland Central America are heavily threatened by deforestation and hydrologic alteration (Anderson et al., 2006). Knowledge of the basic ecology of these fishes can aid in conservation efforts and help fill in the many large gaps in the life history literature.

Because of their relatively low dispersal rates, rapid generation time and remarkable life history diversification, poeciliids are excellent study organisms for understanding life history responses to environmental gradients (Meffe \& Snelson, 1989; Evans et al., 2011). Poeciliids are often used as model systems for investigating the factors contributing to female energy allocation tradeoffs between fecundity and offspring size (Reznick \& Endler, 1982; Grether et al., 2001). Two gradients of particular interest to evolutionary ecologists are predation and food resource availability. Natural experiments have shown that size-selective predation can elicit increased growth rates, earlier maturation, decreased egg size and increased fecundity, and increased overall reproductive output (Reznick et al., 1996). However, these studies are often confounded by covarying longitudinal gradients of increasing food resource availability (Reznick et al., 2001), which can counteract the effects of predation on life history variation. That is, the low productivity and predation rates associated with headwater habitats promote slower growth and reduced fecundity, regardless of predation pressure (Arendt \& Reznick, 2005). While experimental methods have made progress at decoupling the two mechanisms (Grether et al., 2001; Arendt \& Reznick, 2005; Bashey, 2006), a natural scenario with one gradient represented in the absence of the other could help to clarify patterns.

Cusuco National Park (CNP), a high-elevation cloud forest reserve in the Merendon Mountains of northern Honduras, provides an ideal setting for examining life history of poeciliids on a longitudinal stream gradient. Firstly, high elevation, steep relief and low water temperatures create natural barriers that exclude most fish species found in the park's two major river basins (Motagua to the west and Chamelecón/Ulúa to the east, both drain to the Atlantic Ocean). Accordingly, H. bimaculata (senior synonym of Pseudoxiphophorus bimaculatus (Heckel, 1848), according to Page et al., 2013), occurs throughout CNP in the absence of piscine competitors and predators. On the eastern slope of CNP, $H$. bimaculata occurs in isolation between 1025 and 600 meters above sea level (mas). Heterandria bimaculata co-occurs with Xiphophorus mayae Meyer \& Schartl, 2002 at a few locations at elevations below 600 mas in this drainage (but at very low densities), but is rapidly replaced by $X$. mayae in downstream habitats. On the western slope of CNP, $H$. bimaculata occurs in isolation between 700 and 200 mas, and is quickly replaced by Poecilia mexicana Steindachner, 1863, exhibiting a similar pattern to the eastern slope. Giant water bugs (Bellastoma sp.) and Macrobrachium prawns, which can prey on poeciliids (Tobler et al., 2007; McKellar et al., 2009), occur patchily and in low densities throughout CNP. Secondly, although the west side of CNP has experienced patchy deforestation, steep valleys have thus far ensured wide and minimally-disturbed riparian corridors in the entirety of the park. This allows for physicochemical process, and likely productivity (Grether et al., 2001), to change predictably with elevation and stream size. Lastly, stream segments throughout CNP are regularly separated by series of waterfalls. Coupled with the relatively low dispersal rates of poeciliids (Reznick et al., 1996), this discontinuity provides opportunity for punctuated local adaptation by $\mathrm{H}$. bimaculata.

This study addresses two objectives. The first objective was to report the basic life history (i.e. reproductive traits, sex ratio, age-at-maturity, length-weight relationships and growth rates) of $H$. bimaculata in Cusuco National Park, Honduras. This objective provided a unique opportunity to compare life history traits of $H$. bimaculata in CNP to the only other study of $H$. bimaculata, which was conducted in a starkly different habitat (a lowland lake in central Mexico) than the upland streams of CNP (GómezMárquez et al., 1999). The second objective was to examine variation in reproductive traits and growth rates of $H$. bimaculata along an elevational gradient in CNP. Given that food resources should increase along a longitudinal productivity gradient, and that increased food resources have been shown to increase overall reproductive output of poeciliids (Constantz, 1974; Arendt \& Reznick, 2005), it was hypothesized that fecundity, reproductive allotment and growth rates would increase from upstream (e.g. headwaters) do downstream. Because overall reproductive allocation is limited by body cavity size (Constantz, 1989; Reznick \& Endler, 1982; Magurran, 2005), increases in fecundity should accompany decreased egg size.

\section{Material and Methods}

Field and laboratory methods. Thirty sites on six streams (elevations from approximately 1600 to $50 \mathrm{mas}$ ) were sampled during the wet season (12 June through 14 July) of 2013 in Cusuco National Park (Fig.1). Wetted channel widths (m) were measured at ten equally-spaced transects per site, and depth (m) was measured at ten equidistant points on each transect. Water temperature $\left({ }^{\circ} \mathrm{C}\right), \mathrm{pH}$, dissolved oxygen $(\mathrm{mg} / \mathrm{L})$ and conductivity $(\mu \mathrm{S} / \mathrm{cm})$ were recorded using a YSI 556 MPS water quality meter. 

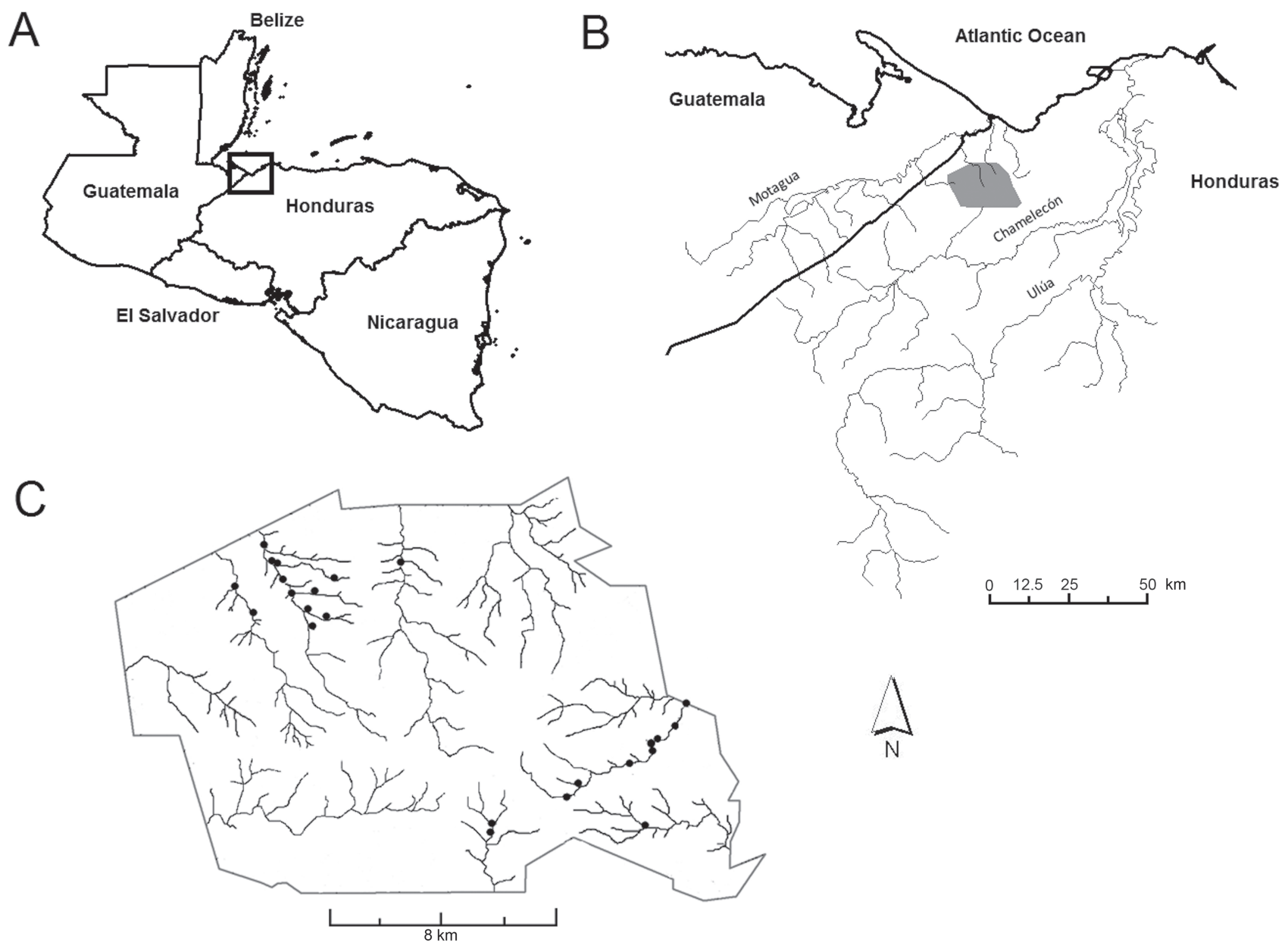

Fig. 1. (A) Mainland Central America, with a square representing the inset of (B), Cusuco National Park (gray) within the río Motagua (Guatemala) and río Chamelecón/Ulúa (Honduras) basins. (C) Sites (black dots) sampled from upstream to downstream on 6 tributaries to the río Motagua (west side) and río Ulua (east side) in Cusuco National Park, Honduras, Central America.

Individuals of $H$. bimaculata were collected using single-pass, single-backpack electrofishing on reach lengths ranging from 50 to $70 \mathrm{~m}$. Macrobrachium prawns, which are also susceptible to backpack electrofishing, were also enumerated. As a proxy for abundance, sampling effort-adjusted catch (catch-per-unit effort [electrofishing time, s], CPUE), and density (total catch divided by mean stream width) of $H$. bimaculata were estimated at each site. At sites where abundance was low ( $<40$ individuals captured), all individuals were preserved in $10 \%$ formalin for laboratory analysis. Where abundance was higher, a subsample of approximately 40 individuals was preserved, representative of the overall size distribution at that site. Remaining individuals were identified to species and sex (if mature; males exhibited distinguishable gonopodia at approximately $30 \mathrm{~mm} \mathrm{TL}$ ), measured to the nearest $\mathrm{mm}$ (total length, TL), and released. Heavy canopy cover at most sites created low light conditions that made accurate field measurements of standard length (SL) difficult; we accordingly estimated SL from a robust sample of lab- measured specimens. Before lab processing, all preserved specimens were soaked in water for at least two hours. Total body weight (g), TL and SL were measured in the lab; specimens were blotted dry before being measured. Gonads of females were then removed and weighed (g), and sagittal otoliths were removed from all individuals. Because most studies report body length measurements in $\mathrm{SL}$, linear regression was used to estimate the relationship between TL and SL in preserved specimens. This equation was used to estimate SL for field-measured individuals for comparison to other studies.

Basic life history. Several basic individual- and populationlevel reproductive traits were measured and summarized. Tertiary (adult) sex ratio was estimated based on all mature collected individuals, not just preserved ones (because sex was determined for each individual before release). Deviation from a 50:50 sex ratio was estimated using a chisquare test of homogeneity. Relationships between total length and embryo count, ovary weight and body weight 
were calculated using regression. Females were considered reproductively mature by the presence of mature eggs in the ovary (Reznick \& Miles, 1989). In males, reproductive maturity was determined by the presence of a fully developed gonopodium (Constantz, 1989). Total embryo count was determined by direct counts. Reproductive allotment (RA), a ratio of the contribution of ovary weight to overall body weight, was calculated according to Reznick \& Endler (1982):

$$
\mathrm{RA}=\frac{\text { dry weight of embryos }}{\text { somatic dry weight }+ \text { dry weight of embryos }}
$$

Embryo development stages were classified according to Haynes (1995). This scheme describes 11 distinct stages, ranging from immature oocyte to the mature embryo ready for birth. Each individual mature female only contained embryos with one developmental stage because $H$. bimaculata does not exhibit superfetation (Marsh-Matthews, 2011). Length at birth was estimated by comparing lengths of stage-11 embryos to lengths of smallest immature individuals captured in the field. For each female, five embryos were randomly selected for measuring egg diameter. Egg diameter was measured using a digital microscope and Leica (LAS V3.8) microsystems software. Differences in average egg diameters among stages were examined using analysis of variance (ANOVA).

Individual fish ages were estimated based on annuli (opaque bands) for 92 males and 142 females using a digital microscope and Leica (LAS V3.8) microsystems software. Opaque and haline (clear) bands correspond to periods of slow and fast (respectively) somatic growth caused by seasonal trends in temperature. Accordingly, otolith-based age estimation for neotropical fishes can be complicated by climactic stability (Tesch, 1971). However, the interior highlands of Honduras experience punctuated wet and dry seasons; wet seasons are characterized by high daily rainfall and lower temperatures. Accordingly, all fishes sampled in this study exhibited distinct otolith banding that can be confidently assigned to one wet season per year; intervals between each opaque band thus represented one year of growth. Ages of each fish were estimated by two independent workers; because of easy readability and low maximum age, agreement between readers was $100 \%$. To estimate growth rates, lengths-atages were back-calculated according to Quist et al. (2013). Annual growth rates were compared between sexes using $t$-tests.

Life history variation. Linear mixed models (LMMs) were used to estimate changes in embryo count, egg diameter, RA and growth rates along the elevation gradient. To account for non-independence among individuals and sites, random effects of individuals, nested within each site were introduced in the LMMS. The effect of female size was accounted for in each model of reproductive traits by including TL as a covariate. No adjustment was made for egg developmental stage because egg diameter did not significantly differ among the stages (analysis of variance, $F_{10,78}=1.869, p=0.0650$ ). Distributions of all response variables were examined prior to analysis; embryo count and reproductive allotment were log-transformed to achieve approximate normality. Linear regression was used to estimate sex-specific changes in maximum total length. Five sites in which $H$. bimaculata co-occurred with other poeciliids (X. mayae or P. mexicana) were excluded from this analysis because (a) abundance of $H$. bimaculata was reduced in the presence of other species, prohibiting an adequate sample of individuals, and (b) potential effects of competition and/or predation can affect life history parameters, and the few sites at which $H$. bimaculata occurred with other species inhibited robust analysis of these factors. All analyses were conducted in R version 3.0.3 (R Development Core Team, 2014).

\section{Results}

Basic life history. A total of 811 individuals were captured among 21 sites. Fish were not captured at elevations greater than $1025 \mathrm{~m}$ on the eastern slope of CNP (7 sties), or greater than $700 \mathrm{~m}$ on the western slope (2 sites). Of those 811 individuals, $286(35 \%)$ were mature males, 332 (41\%) were mature females, and 193 (24\%) were immature. The overall sex ratio was 1:1.1 male to female, which was not significantly different from $1: 1\left(\chi_{2,617}^{2}=3.4\right.$, $p=0.0602$ ).

Female SL was predicted by the equation: $S L=0.8736^{*} T L-2.6125\left(R^{2}=0.98, p<0.0001\right)$; this model predicted SL of $95 \%$ of individuals to within $2 \mathrm{~mm}$ of the known SL. Male SL was predicted by the equation: $S L=0.8128^{*} T L+0.2399\left(R^{2}=0.93, p<0.0001\right)$; this model predicted SL of $98 \%$ of individuals to within $2 \mathrm{~mm}$ of the known SL. For consistency within this study, we report only TL, but provide the equations for drawing future comparisons. Male weight $\left(p<0.0001, R^{2}=0.91\right)$, female weight $\left(p<0.0001, R^{2}=0.99\right)$, embryo count $(p=0.0024$, $\left.R^{2}=0.23\right)$, and gonad weight $\left(p<0.0001, R^{2}=0.52\right)$ were positively related to total length (Fig. 2). Standard lengths at first reproduction were $27 \mathrm{~mm}( \pm 2 ; 30 \mathrm{TL})$ for males and $40 \mathrm{~mm}$ for females, respectively. Embryo counts ranged from 7 to 79 per individual, and average egg diameters ranged from $1.61 \mathrm{~mm}$ to $2.56 \mathrm{~mm}$.

Maximum observed female and male TL were $91 \mathrm{~mm}$ and $63 \mathrm{~mm}$, respectively. Maximum observed female and male weights were $9.96 \mathrm{~g}$ and $1.85 \mathrm{~g}$, respectively. Females lived longer than males. Females reached a maximum of age- $2^{+}$, while males only lived to age $-1^{+}$; no age- $2^{+}$males were observed (Table 1 ). Females also grew faster than males during both growth intervals (age- 0 to age-1+: $t_{2,202}=-5.47, p<0.0001$; age-1+ to age- $2+: t_{2,202}=-$ 9.35, $p<0.0001$ ) (Table 1). 

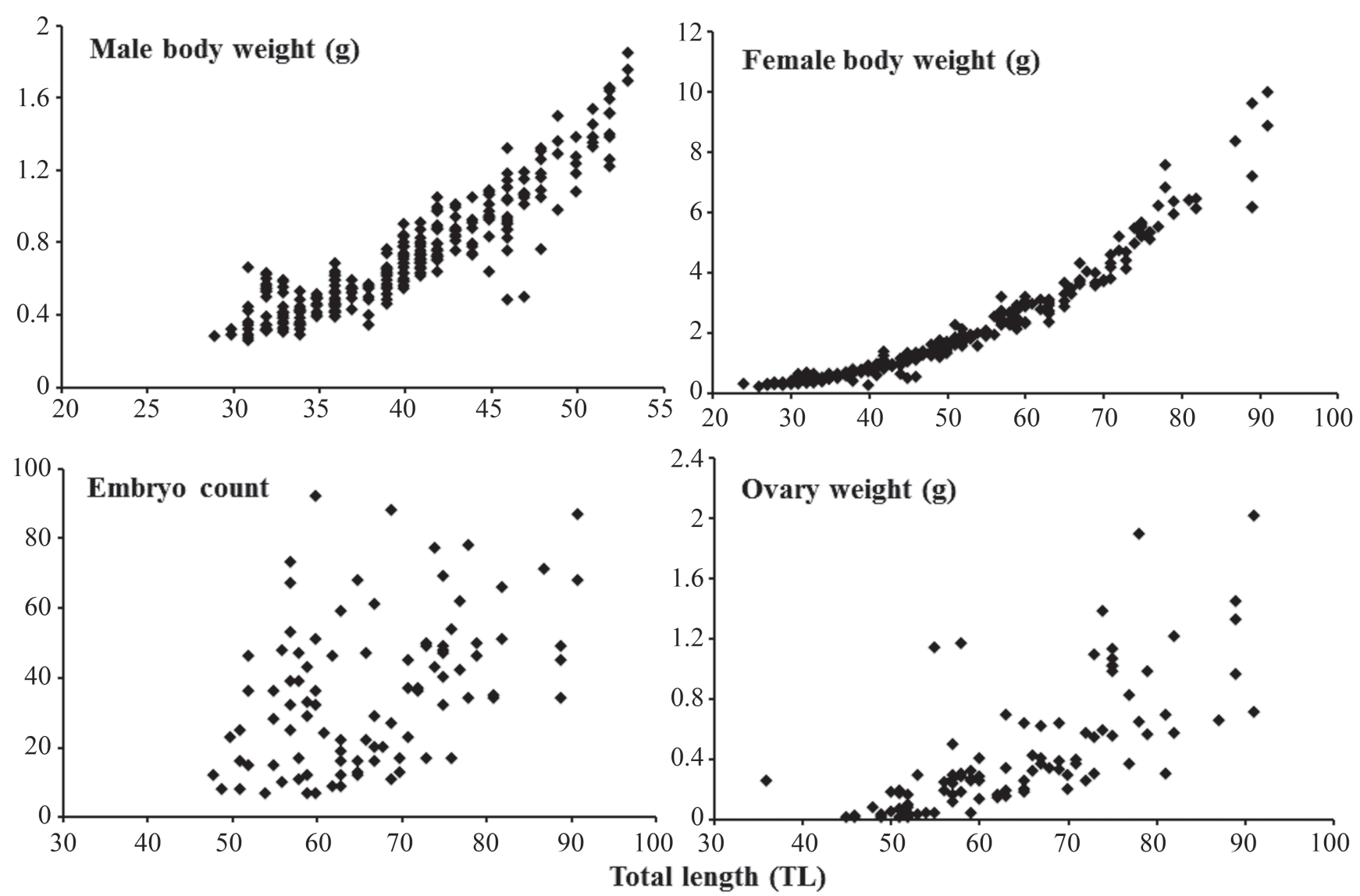

Fig. 2. Relationships between male and female body weights, embryo counts, ovary weights and total length of Heterandria bimaculata in Cusuco National Park, Honduras in summer 2013.

Table 1. Observed and back-calculated lengths at ages ( \pm standard error) for Heterandria bimaculata in Cusuco National Park, Cortes Dept., Honduras.

\begin{tabular}{lcccc}
\hline & \multicolumn{2}{c}{ Female } & \multicolumn{2}{c}{ Male } \\
\cline { 2 - 5 } Age & Observed & Back-calculated & Observed & Back-calculated \\
\hline Age-0 & $44.4 \pm 0.90$ & $36.4 \pm 0.66$ & $40.9 \pm 0.88$ & $31.9 \pm 0.63$ \\
Age-1+ & $58 \pm 0.78$ & $59.9 \pm 2.1$ & $46.1 \pm 0.82$ & - \\
Age-2+ & $78.6 \pm 0.80$ & - & - & - \\
\hline
\end{tabular}

Changes with elevation. All water quality variables changed predictably with elevation. Conductivity $\left(p=0.0011, \quad R^{2}=0.36\right), \mathrm{pH} \quad\left(p=0.0091, \quad R^{2}=0.25\right) \quad$ and temperature $\left(p<0.0001, R^{2}=0.63\right)$ all increased as streams progressed downstream and decreased in elevation. Dissolved oxygen decreased with elevation $(p=0.0030$, $R^{2}=0.31$. Mean channel width increased noticeably, but not significantly, from upstream to downstream $\left(p=0.0677, R^{2}=14\right)$. Specific physiochemical variables were not used to predict variation in $H$. bimaculata life history because they were so closely correlated with elevation (Fig. 3). Instead, only elevation itself was used as the independent variable predicting $H$. bimaculata life history variation.
Heterandria bimaculata exhibited variation in reproductive traits and growth rates along the elevational gradient. From upstream to downstream, females produced more but smaller eggs, but did not allocate differing proportions of body mass to gonad production. Linear mixed models revealed significant negative effects of elevation on length-adjusted fecundity $(p<0.0001)$. Conversely, average egg diameter increased positively with elevation $(p<0.0001)$. However, reproductive allotment did not change along the elevational gradient $(p=0.2279)$. Female TL was a significant covariate in each model ( $p<0.0001$ for all).

Female growth rates showed no changes with elevation during any annual interval (age- 0 to age-1: $p=0.7520$; age- $1+$ to age $2+: p=0.5974$; age $2+$ to capture: $p=0.4050$ ). Further, neither average nor maximum female total length showed any relationship with elevation $(p=0.8410$ and 0.6256 , respectively). On the other hand, males grew faster and larger from downstream to upstream. Age$1+$ growth rates $(p=0.0070)$ and maximum total lengths ( $p=0.0025)$ of males decreased sharply with increased elevation. CPUE of $H$. bimaculata increased from upstream $\left(p=0.0365, R^{2}=0.26\right)$, but, fish density (total catch divided by average channel width) did not change significantly with elevation ( $p=0.1284, R^{2}=0.16$ ) (Fig. 4). 

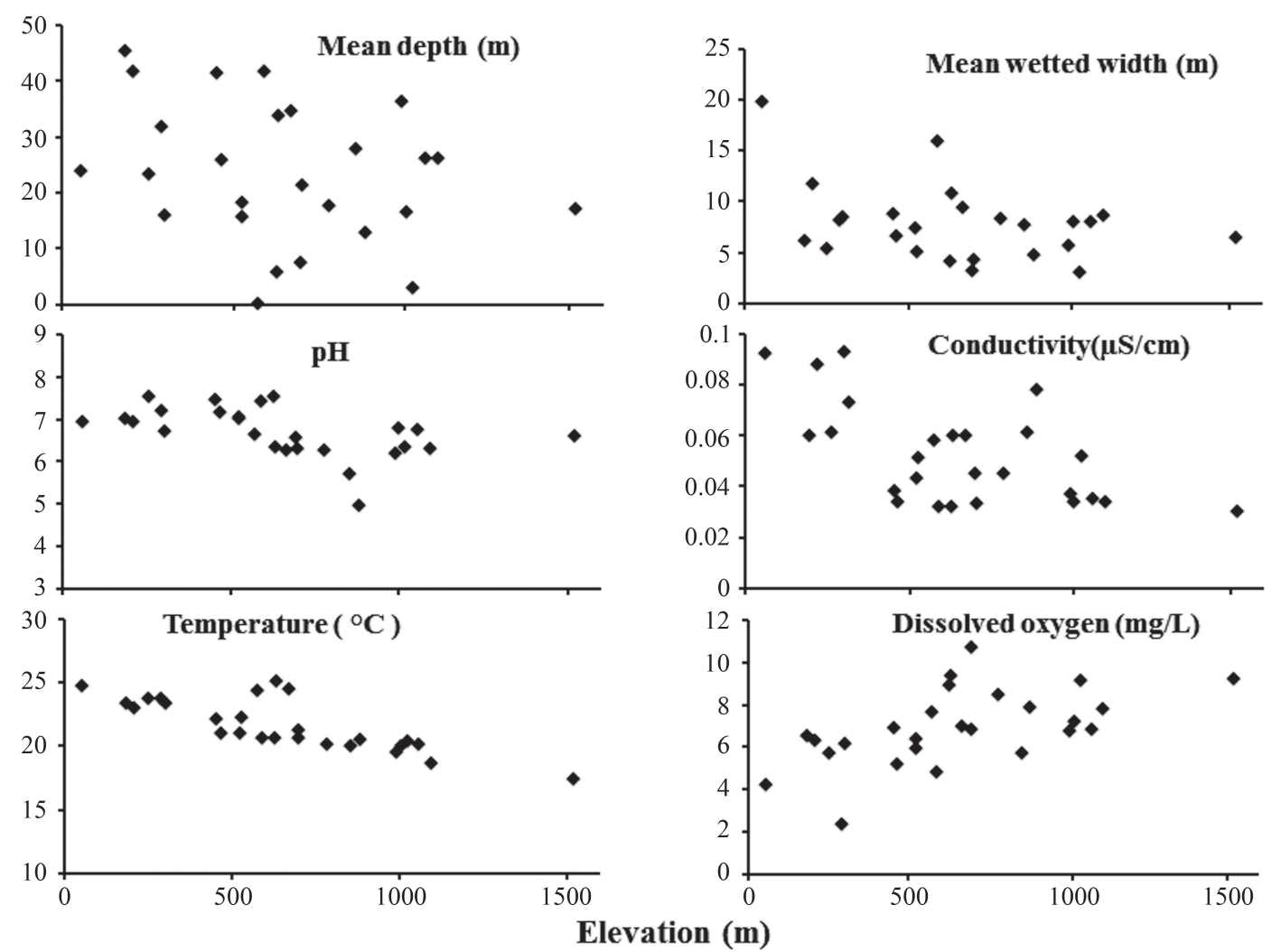

Fig. 3. Changes in physicochemical parameters of streams along an elevation gradient in Cusuco National Park, Honduras in summer 2013.
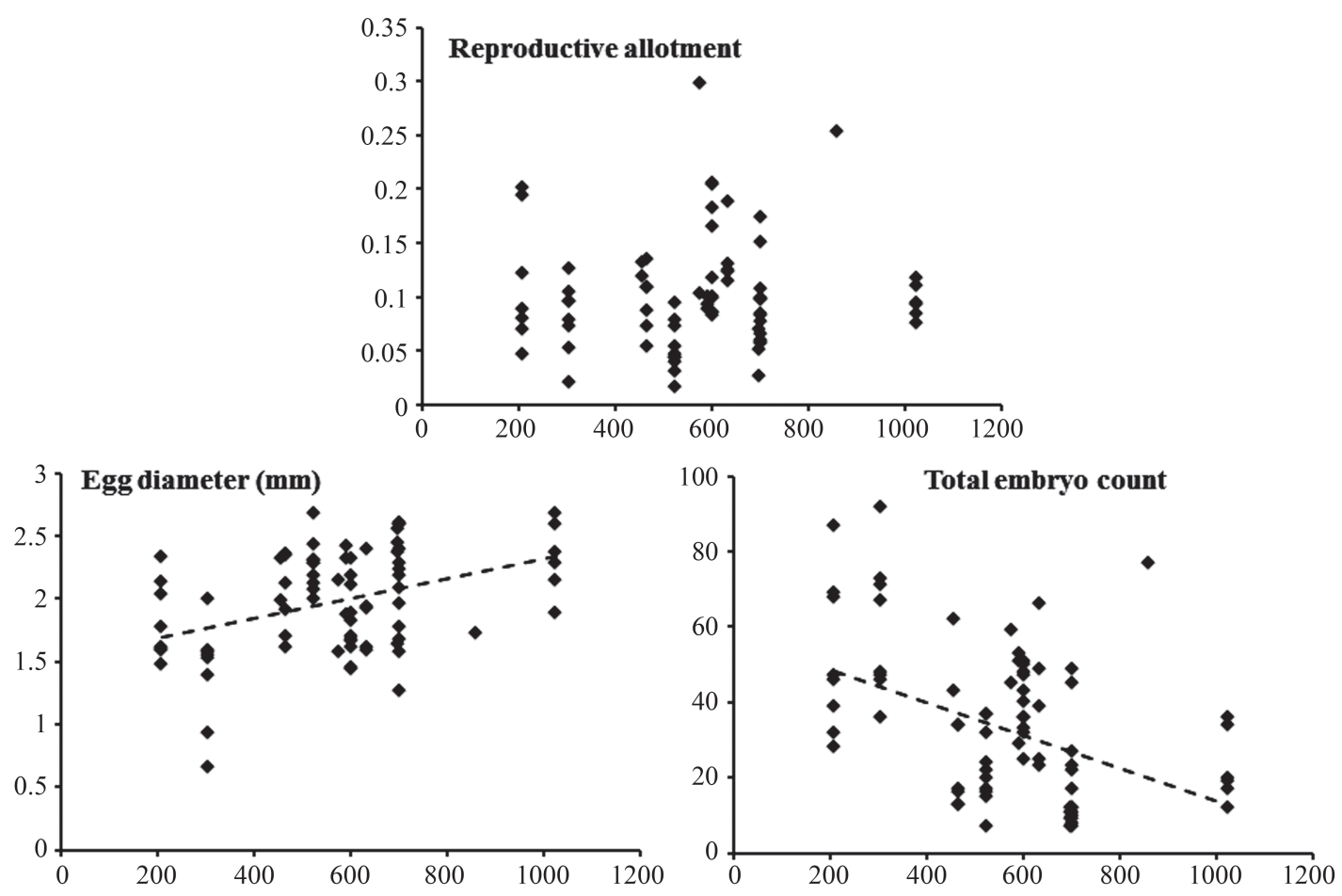

Elevation (m)

Fig. 4. Changes in reproductive traits of female Heterandria bimaculata along an elevational gradient in Cusuco National Park, Honduras in summer 2013. Points represent actual values. Dashed lines represent fitted means from linear mixed models, accounting for nested effects of individual variability within sites, and total length of individuals. No fitted line is presented for reproductive allotment because this variable did not change significantly along the elevational gradient. 


\section{Discussion}

Understanding life history variation across a broad spectrum of geographic and environmental contexts can provide deeper insight into the mechanisms that drive largerscale biological processes. This paper represents one of the few life history studies of poeciliids in the Central American interior highlands. Life history traits of $H$. bimaculata observed in this study present intriguing similarities and differences to those reported by Gómez-Márquez et al. (1999), the only other study of $H$. bimaculata, conducted on a lowland lake in central Mexico. Firstly, H. bimaculata in CNP exhibited a relatively balanced tertiary sex ratio. This contrasts with the majority of studies on various poeciliids (Vargas \& Sostoa 1996; Cabral \& Marques, 1999; Zúñiga-Vega et al., 2012) and specifically for H. bimaculata (Gómez-Márquez et al., 1999), which report female-biased population structure. Female-biased sex ratios in poeciliids arise typically because males are more susceptible to mortality from numerous factors such as predation, resource limitation, hypoxia and extreme temperatures, largely because they devote such high energetic allocations to courtship (Snelson, 1989; Rodd \& Reznick, 1997; Pettersson et al., 2004; Arendt et al., 2014). Alternatively, Arendt et al. (2014) suggested that differential mortality rates between sexes can bias snapshot analyses of sex ratios, depending on sampling season. Long-term analysis of the demographics of predator-free poeciliid populations would help to better describe the effects of predation on sex ratios. In the present study, $H$. bimaculata occurred in absence of major avian or fish predators, hence the approximately equal sex ratio. No piscivorous birds were observed during sampling, and H. bimaculata was the only fish species captured at the majority of sites. Furthermore, only two Macrobrachium prawns were captured in the entire study. Additionally, predatory Bellastoma were seldom encountered in concurrent (unpublished) invertebrate sampling at each site. This, coupled with several lines of life history evidence, indicates an environment of very low predation rates on H. bimaculata. Although predation rates are low in CNP, it is not implied that predators are non-existent. Future work should seek to quantify all potential sources of predation, rather than only fish-based predation.

Growth patterns of $H$. bimaculata in CNP also showed interesting similarities and differences to lowland conspecifics in central Mexico. Firstly, maximum size of males was considerably smaller in CNP. Gómez-Márquez et al. (1999) observed a maximum male SL of $60 \mathrm{~mm}$. Converted to TL based on the equation derived from the TL-SL relationship in CNP, this equates to $74 \pm 2 \mathrm{~mm}$, which is 10 to $14 \mathrm{~mm}$ larger than the largest male captured in CNP. Females, on the other hand, grew larger in CNP; the largest female captured in CNP was $76 \mathrm{~mm}$ SL (91 mm TL), which is $9 \mathrm{~mm}$ larger than the maximum female SL captured by Gómez-Márquez et al. (1999). Heterandria bimaculata also grew considerably faster in the lowland lake in central
Mexico, reaching $80 \%$ (females) and $86 \%$ (males) of their maximum length by six months of age, then growing very little for the following 18 months (Gómez-Márquez et al., 1999). Males in CNP exhibited patterns typical of poeciliids: rapid growth to maturity, followed by little post-maturation growth (Snelson, 1982, 1984; Zulian et al., 1995). Females continued growth after maturation, reaching $48 \%$ and $63 \%$ of their maximum length by the ends of first and second year growth, respectively.

The dramatically different growth patterns in $H$. bimaculata between the lowland central Mexico lake and CNP likely represent contrasting abiotic and predation conditions. One important abiotic feature is temperature, which was distinctly lower in CNP (16.9 to $25.1^{\circ} \mathrm{C}$ vs. 23 to $29^{\circ} \mathrm{C}$ in the central Mexico lake) and could have contributed to decreased growth rates (Wurtsbaugh \& Cech, 1983; Vondracek et al., 1988). While water temperatures probably are higher in CNP streams during the dry season (during which no measurements were made), the high elevation and heavily-forested riparian corridors likely prevent temperatures as high as those reported by Gómez-Márquez et al. (1999). In fact, Lorion et al. (2011) reported dry season stream temperatures in Costa Rican streams of similar elevation that were comparable to the wet season temperatures recorded in CNP. It is consequently safe to assume that annual temperatures experienced by $H$. bimaculata in CNP are lower than those reported by Gómez-Márquez et al. (1999).

Growth patterns of $H$. bimaculata in CNP may also be a result of a mild predation regime. Environments with size-selective predation regimes typically favor faster-growing individuals that mature earlier (Reznick \& Endler, 1982; Reznick et al., 2001). Heterandria bimaculata grew considerably slower and matured later in CNP than in the lowland lake in Mexico. This pattern is consistent with a low-predation environment. Because predators are relatively lacking in CNP, there is likely little selective pressure for faster-growing individuals. Instead, greater fitness gains are likely to be made through delayed maturation and slower growth, not through increased longevity and maximum size.

Heterandria bimaculata in CNP exhibited a tradeoff between fecundity and offspring size along the elevational gradient. These patterns could represent responses to several factors that change predictably along longitudinal gradients in streams. The most likely mechanism is a gradient of productivity, and thus food resources. It is well understood that stream productivity increases from upstream to downstream (Vannote et al., 1980). Additionally, female poeciliids have been shown to exhibit reduced fecundity and larger offspring size as food resources become scarce (Constantz, 1974; but see Grether \& Kolluru, 2011 for a review). Thus, the observed pattern of increasing fecundity and egg volume while decreasing egg size from upstream to downstream is consistent with a resource-limitation hypothesis. Female fishes can 
maximize fitness by optimizing reproductive allocation with corresponding tradeoffs, but increased body size and growth investment may only confer greater fitness in absence of limiting extrinsic ecological factors (Stearns, 2000). Consequently, in predator-free environments, less fitness gains stand to be made from altering growth rate than egg production. Males, however, allocate much less energy to reproductive tissue production. Male poeciliids are more likely to maximize fitness by increasing body size, which is useful for combative intraspecific competition for mates (Morris et al., 1992; Bisazza, 1993). Differences in energy allotments, reproductive tissue (female) versus secondary sexual characteristics (male), help explain the different relationships of growth rate and elevation between female and male $H$. bimaculata in CNP.

Fish density can also have strong effects on patterns of reproductive allocation (Leips et al., 2009). However, the patterns observed in this study are unlikely to be due to density dependence. Firstly, abundance of $H$. bimaculata increased from upstream to downstream, but so did stream size. Accordingly, fish density did not change along the gradient. Secondly, even if the longitudinal trend in density was significant, $H$. bimaculata should be expected to exhibit decreasing, not increasing, investment in offspring size with density because of intraspecific competition (Dahlgren, 1979; Bashey, 2008). However, if resources were truly more limiting in upstream habitats, and since density was fairly constant among sites, then per-capita resource availability should increase longitudinally. In which case, intraspecific competition for food resources would be higher in upstream habitats. This would favor the production of fewer, larger offspring which are more competitive in resource-limited or harsher upstream environments (Brasher et al., 2006; Riesch et al., 2012), and transition to production of more but smaller offspring as competition becomes less of a limiting factor in less dense downstream habitats.

Water quality also changed predictably from upstream to downstream. While all water quality variables measured in this study have been shown to affect reproductive characteristics of poeciliids (Rubin, 1985; Edwards et al., 2006), one of the most important is temperature. Indirectly, the temperature patterns observed in CNP can work in conjunction with longitudinally increasing nutrient input and insolation to influence productivity. Increasing temperature from upstream to downstream can directly and positively affect growth rates through metabolic pathways. However, if temperature were the only factor influencing $H$. bimaculata life history in CNP, growth rates of both sexes would have increased along the gradient. Evidence of temperature as a limiting factor may exist in the distributional patterns of fishes in CNP. Distributions of mobile species such as Agonostomus monticola (Bancroft, 1834), Sicydium punctatum Perugia, 1896 and Rhamdia laticauda (Kner, 1858) were clearly delineated by waterfalls. However, no obvious physical barriers existed between sites where $H$. bimaculata was present and absent. In fact, sites containing $H$. bimaculata were often separated by several waterfalls or cascade complexes of 3 to $10 \mathrm{~m}$ in height. Proceeding upstream, $H$. bimaculata simply decreased in abundance until it was altogether absent. These patterns existed independently of stream size, as H. bimaculata was captured in several tiny streams $(<1 \mathrm{~m}$ wide) at medium and low elevations. These observations, coupled with its widespread distribution in the Central American lowlands, suggest $H$. bimaculata exists near its lower thermal limit in high elevation streams of the Honduran interior highlands.

The interior highlands of Central America represent different habitats and geologic histories from the more heavily-studied Caribbean islands and mainland lowlands. Future work on poeciliid life history in this region can yield additional insights into how life history traits change along natural gradients. This study demonstrates that in environments with reduced predation rates, reproductive traits of poeciliids change predictably with elevation. Future work should seek to describe the mechanisms that drive this pattern. Attempts to decouple the relative effects of food resource availability, thermal gradients, and potential effects of invertebrate predators will be a useful first step. A combination of in-situ estimates of productivity and experimental approaches to isolate potential effects of density would also be informative.

\section{Acknowledgements}

This project was funded by Operation Wallacea. We thank Anarda Salgado for invaluable field and lab assistance, as well as local faunal expertise. Several local guides and Operation Wallacea volunteers also provided field assistance. We also thank Steve Green for providing logistical support, and Oliver Burdekin for spatial data. Wilfredo Matamoros and an anonymous reviewer provided comments that greatly improved the manuscript. All research was conducted in compliance with Institutional Animal Care and Use Committee (IACUC) standards. Voucher specimens of all species collected in this study were deposited in the Honduras Museum of Natural History, and in the ichthyologogical collection at Virginia Polytechnic Institute and State University (POEC-13-01).

\section{References}

Anderson, E. P., M. C. Freeman \& C. M. Pringle. 2006. Ecological consequences of hydropower development in Central America: impacts of small dams and water diversion on neotropical stream fish assemblages. River Research and Applications, 22: 397-411.

Angulo, A., C. A. Garita-Alvarado, W. A. Bussing \& M. I. López. 2013. Annotated checklist of the freshwater fishes of continental and insular Costa Rica: additions and nomenclatural revisions. Check List, 9: 987-1019.

Arendt, J. D. \& D. N. Reznick. 2005. Evolution of juvenile growth rates in female guppies (Poecilia reticulata): predator regime or resource level? Proceedings of the Royal Society B, 272: 333-337. 
Arendt, J. D., D.N. Reznick \& A. López-Sepulcre. 2014. Replicated origin of female-biased adult sex ratio in introduced populations of the Trinidadian guppy (Poecilia reticulata). Evolution, 68: 2343-2356.

Bashey, F. 2006. Cross-generational environmental effects and the evolution of offspring size in the Trinidadian guppy Poecilia reticulata. Evolution, 60: 348-361.

Bashey, F. 2008. Competition as a selective mechanism for larger offspring size in guppies. Oikos, 117: 104-113.

Bisazza, A. 1993. Male competition, female mate choice and sexual size dimorphism in poeciliid fishes. Pp. 257-286. In: Huntingford, F.A. \& Torricelli (Eds.). Behavioural ecology of fishes. Chur, Switzerland, Hardwood Academic. (Ettore Majorana international life sciences series, v.11).

Brasher, A. M. D., C. D. Luton, S. L. Goodbred \& R. H. Wolff. 2006. Invasion patterns along elevation and urbanization gradients in Hawaiian streams. Transactions of the American Fisheries Society, 135: 1109-1129.

Cabral, J. A. \& J. C. Marques. 1999. Life history, population dynamics and production of eastern mosquitofish, Gambusia holbrooki (Pisces, Poeciliidae), in rice fields of the lower Mondego River Valley, western Portugal. Acta Oecologica, 20: 607-620.

Constantz, G. D. 1974. Reproductive effort in Poeciliopsis occidentalis (Poeciliidae). The Southwestern Naturalist, 19: 47-52.

Constantz, G. D. 1989. Reproductive biology of poeciliid fishes. Pp. 33-50. In: Meffe, G. K. \& J. F.F. Snelson, Jr. (Eds.). Ecology and evolution of livebearing fishes (Poeciliidae). Englewood Cliffs, NJ, Prentice Hall.

Dahlgren, B. T. 1979. The effects of population density on fecundity and fertility in the guppy, Poecilia reticulata (Peters). Journal of Fish Biology, 15: 71-91.

Edwards, T. M., H. D. Miller \& L. J. Guillette, Jr. 2006. Water quality influences reproduction in female mosquitofish (Gambusia holbrooki) from eight Florida springs. Environmental Health Perspectives, 114 (suppl. 1): 69-75.

Esselman, P. C., M. C. Freeman \& C. M. Pringle. 2006. Fishassemblage variation between geologically defined regions and across a longitudinal gradient in the Monkey River Basin, Belize. Journal of the North American Benthological Society, 25: 142-156.

Evans, J. P., A. Pilastro \& I. Schlupp (Eds.). 2011. Ecology and evolution of poeciliid fishes. Chicago, Chicago University Press, 409p.

Gómez-Márquez, J. L., J. L. Guzmán-Santiago \& A. Olvera-Soto. 1999. Reproducción y crecimiento de Heterandria bimaculata (Cyprinodontiformes: Poeciliidae) en la Laguna "El Rodeo", Morelos, México. Revista de Biologia Tropical, 47: 581-592.

Grether, G. F. \& G. R. Kolluru. 2011. Evolutionary and plastic responses to resource availability. Pp. 61-71. In: Evans, J.P, A. Pilastro \& I. Schlupp (Eds.). Ecology and evolution of poeciliid fishes. Chicago, University of Chicago Press.

Grether, G. F., D. F. Millie, M. J. Bryant, D. N. Reznick \& W. Mayea. 2001. Rain forest canopy cover, resource availability, and life history evolution in guppies. Ecology, 82: 1546-1559.

Haynes, J. L. 1995. Standardized classification of poeciliid development for life-history studies. Copeia, 1995(1): 147-154.

Leips, J., J. M. L. Richardson, F. H. Rodd \& J. Travis. 2009. Adaptive maternal adjustments of offspring size in response to conspecific density in two populations of the least killifish, Heterandria formosa. Evolution, 63: 1341-1347.
Lorion, C. M., B. P. Kennedy \& J. H. Braatne. 2011. Altitudinal gradients in stream fish diversity and the prevalence of diadromy in the Sixaola River basin, Costa Rica. Environmental Biology of Fishes, 91: 487-499.

Lyons, J. 2005. Distribution of Sicydium Valenciennes 1837 (Pisces: Gobiidae) in Mexico and Central America. Hydrobiológica, 15: 239-243.

Magurran, A. E. 2005. Evolutionary ecology: the Trinidadian guppy. Oxford, Oxford University Press, 206p.

Marsh-Matthews, E. 2011. Matrotrophy. Pp 18-27. In: Evans, J. P., J. Pilastro \& I. Schlupp (Eds.). Ecology and evolution of poeciliid fishes. Chicago, University of Chicago Press.

Matamoros, W. A., B. R. Kreiser \& J. F. Schaefer. 2012. A delineation of nuclear Middle America biogeographical provinces based on river basin faunistic similarities. Reviews in Fish Biology and Fisheries, 22: 351-365.

Matamoros, W. A., C. D. McMahan, P. Chakrabarty, J. S. Albert \& J. F. Schaefer. 2015. Derivation of the freshwater fish fauna of Central America revisited: Myers's hypothesis in the twentyfirst century. Cladistics, 31: 177-188.

Matamoros, W. A., J. F. Schaefer \& B. R. Kreiser. 2009. Annotated checklist of the freshwater fishes of continental and insular Honduras. Zootaxa, 2307: 1-38.

McKellar, A. E., M. M. Turcotte \& A. P. Hendry. 2009. Environmental factors influencing adult sex ratio in Trinidadian guppies. Oecologia, 159: 735-745.

McMahan, C. D., W. A. Matamoros, F. S. A. Calderon, W. Y. Henriquez, H. M. Recinos, P. Chakrabarty, E. Barraza \& N. Herrera. 2013. Checklist of the inland fishes of El Salvador. Zootaxa, 3608, 440-456.

Meffe, G. K. \& F. F. Snelson, Jr. 1989 (Eds.). Ecology and evolution of livebearing fishes (Poeciliidae). Englewood Cliffs, Prentice Hall, NJ, 453p.

Miller, R. R. 1966. Geographical distribution of Central American freshwater fishes. Copeia, 1966(4): 773-802.

Morris, M. R., P. Batra \& M. J. Ryan. 1992. Male-male competition and access to females in the swordtail Xiphophorus nigrensis. Copeia, 1992(4): 980-986.

Page, L. M., H. Espinosa-Pérez, L. D. Findley, C. R. Gilbert, R. N. Lea, N. E. Mandrak, R. L. Mayden \& J. S. Nelson. 2013. Common and scientific names of fishes from the United States, Canada, and Mexico. 7th ed. Bethesda, MD, American Fisheries Society, 384p. (Special Publication, no. 34).

Pettersson, L. B., I. W. Ramnarine, S. A. Becher, R. Mahabir \& A. E. Magurran. 2004. Sex ratio dynamics and fluctuating selection pressures in natural populations of the Trinidadian guppy, Poecilia reticulata. Behavioral Ecology and Sociobiology, 55: 461-468.

Quist, M. C., M. A. Pegg \& D. R. DeVries. 2013. Age and Growth. Pp. 677-731. In: Zale, A. V., D. L. Parrish \& T. M. Sutton (Eds.). Fisheries techniques, $3^{\text {rd }}$ ed. Bethesda, MD, American Fisheries Society.

R Development Core Team. 2014. R: A language and environment for statistical computing [Computer software manual]. Vienna, Austria, R Foundation for Statistical Computing.

Reznick, D. N., M. J. Butler IV \& H. Rodd. 2001. Life-history evolution in guppies. VII. The comparative ecology of high- and lowpredation environments. The American Naturalist, 157: 12-26.

Reznick, D. N., M. J. Butler IV, F. H. Rodd \& P. Ross. 1996. Lifehistory evolution in guppies (Poecilia reticulata). Differential mortality as a mechanism for natural selection. Evolution, 50: 1651-1660. 
Reznick, D. N. \& J. A. Endler. 1982. The impact of predation on life history evolution in Trinidadian guppies (Poecilia reticulata) 6. Differential mortality as a mechanism for natural selection. Evolution, 36: 160-177.

Reznick, D. N. \& D. B. Miles. 1989. Review of life history patterns in poeciliid fishes. Pp. 125-148. In: Meffe, G. K. \& F. F. Snelson, Jr. (Eds.). Ecology and evolution of livebearing fishes (Poeciliidae). Englewood Cliffs, NJ, Prentice Hall.

Riesch, R., M. Plath \& I. Schlupp. 2012. The offspring size/ fecundity trade-off and female fitness in the Atlantic molly (Poecilia mexicana, Poeciliidae). Environmental Biology of Fishes, 94: 457-463.

Rodd, F. H. \& D. N. Reznick. 1997. Variation in the demography of guppy populations: the importance of predation and life histories. Ecology, 78: 405-418.

Rubin, D. A. 1985. Effect of $\mathrm{pH}$ on sex ratio in cichlids and a Poeciliid (Teleostei). Copeia, 1985(1): 233-235.

Snelson, F. F., Jr. 1982. Indeterminte growth in males of the sailfin molly, Poecilia latipinna. Copeia, 1982(2): 252-255.

Snelson, F. F., Jr. 1984. Seasonal maturation and growth of males in a natural population of Poecilia latipinna. Copeia 1984(1): 252-255.

Snelson, F. F., Jr. 1989. Social and environmental control of life history traits in poeciliid fishes. Pp. 149-161. In: Meffe, G. K. \& F.F. Snelson, Jr. (Eds.). Ecology and evolution of livebearing fishes (Poeciliidae). Englewood Cliffs, NJ, Prentice Hall.

Stearns, S. C. 2000. Life history evolution: successes, limitations, and prospects. Naturwissenschaften, 87: 476-486.

Tesch, F. W. 1971. Age and growth. Pp. 93-123. In: Ricker, W.E. (Ed.). Methods for assessment of fish production in fresh waters, $2^{\text {nd }}$ printing. London, International Biological Programme; Oxford, Blackwell Scientific (IBP handbook, no. 3)
Tobler, M., I. Schlupp \& M. Plath. 2007. Predation of a cave fish (Poecilia mexicana, Poeciliidae) by a giant water-bug (Belostoma, Belostomatidae) in a Mexican sulphur cave. Ecological Entomology, 32: 492-495.

Vannote, R. L., G. W. Minsall, K. W. Cummings, J. R. Sedell \& C. E. Cushing. 1980. The river continuum concept. Canadian Journal of Fisheries and Aquatic Sciences, 37: 130-137.

Vargas, M. J. \& A. de Sostoa. 1996. Life history of Gambusia holbrooki (Pisces, Poeciliidae) in the Ebro delta (NE Iberian peninsula). Hydrobiologia, 341: 215-224.

Vondracek, B., W. A. Wurtsbaugh \& J. J. Cech, Jr. 1988. Growth and reproduction of the mosquitofish, Gambusia affinis, in relation to temperature and ration level: consequences for life history. Environmental Biology of Fishes, 21: 45-57.

Wurtsbaugh, W. A. \& J. J. Cech, Jr. 1983. Growth and activity of juvenile mosquitofish: temperature and ration effects. Transactions of the American Fisheries Society, 112: 653-660.

Zulian, E., A. Bisazza \& G. Marin. 1995. Variations in male body size in natural populations of Gambusia holbrooki. Ethology Ecology \& Evolution, 7: 1-10.

Zúñiga-Vega, J. J., A. L. Hernández-Rosas, A. MolinaMoctezuma, H. A. Peréz-Mendoza, F. R. Rodríguez-Reyes, Y. M. Bravo-Espinosa \& H. Espinoza-Pérez. 2012. Population abundance and sex ratio of the viviparous freshwater fish Poeciliopsis baenschi (Poeciliidae) throughout its range in western Mexico. Western North American Naturalist, 72: 357-368.
Submitted April 28, 2015

Accepted August 15, 2015 by Carmen Montaña 